\title{
Ortadoğu'daki Yapısal Değişimin Devletlerin İttifak Politikalarına Etkisi: Suriye Örneği
}

\author{
Furkan Polat*
}

Öz

Bu çalışma, Ortadoğu'da meydana gelen sistemik değişimden yola çıkarak Suriye krizi bağlamında 2011-2015 yılları arasında kurulan ittifakları kuramsal bir bakış açısıyla incelemektedir. Bu sistemik değişimin miladı, Obama yönetiminin seleflerinden farklılaşan dış politika yaklaşımına dayanmaktadır. Obama doktrini olarak isimlendirilen yeni dış politika, kriz alanlarına yönelik sorumluluk üstlenmekten kaçınma ve bu sorumluluğu daha çok bölgesel aktörlere yükleme anlayışı üzerine inşa edilmiştir. Sistemik değişimle birlikte bölgesel güç dağılımının devlet davranışlarında belirleyici olması, bu davranışlardan biri olan ittifakların yeni sistemik özellikler 1şı̆̆ında tanımlanmasını zaruri kılmaktadır. Bu bağlamdan hareketle çalışma, Suriye örneği üzerinden yeni sistemik sınırlar içerisinde kurulan ittifakların ardında yatan kaygının güvenlik merkezli olduğu iddia etmektedir.

Anahtar Kelimeler: İttifaklar, Suriye Krizi, Obama Doktrini, Çok Kutuplu Sistem, Tehdit Dengesi

* Arş.Gör., Sakarya Üniversitesi, Ortadoğu Enstitüsü, furkanpolat25@gmail.com 


\title{
The Impact of Structural Change in the Middle East on Alliance Policies of States: The Case of Syria
}

\author{
Furkan Polat*
}

\begin{abstract}
This study examines the alliances established between 2011-2015 in the context of the Syrian crisis from the theoretical perspective of considering the systemic change that took place in the Middle East. The milestone of this systemic change is based on a foreign policy approach that differs from the predecessors of the Obama administration. The new foreign policy, called as the Obama doctrine, is built on an understanding of avoidance of responsibility for crisis areas and a sense of putting the responsibility on regional actors. The fact that regional power distribution with systemic change is determinative of state behavior makes it necessary to identify alliances which are one of these behaviors, in the light of new systemic features. Starting from this context the study asserts that the concern lies behind the alliances established within the new systemic borders over the Syrian example is security oriented.
\end{abstract}

Keywords: Alliances, Syrian Crisis, Obama Doctrine, Multipolar System, Balance of Threat

* Res. Asst., Sakarya University, Middle East Institute, furkanpolat25@gmail.com 


\section{Giriş}

25 Aralık 1991'de Sovyetler Birliği'nin dağılması, İkinci Dünya SavaŞ1 sonrası ABD ile SSCB arasındaki güç mücadelesini ifade eden Soğuk Savaş'1 sona erdirmekle kalmamış aynı zamanda bu rekabetin yaşandığ 1 iki kutuplu küresel sistemdeki güç dağılımını dönüşüme uğratmıştır. $\mathrm{Bu}$ sistemik değişim, ABD'nin dengelenemez üstünlüğünün kabul edildiği ve Soğuk Savaş döneminin rekabet alanlarının büyük ölçüde ABD tarafından domine edildiği tek kutuplu güç dağılımına evrilmiştir. Devletler üstü bir otoriteden yoksun anarşik tek kutuplu sistemde ABD'nin güç dağılımındaki eşsiz konumu, onun davranışlarını sistemdeki diğer devletlerin davranışlarını etkileyen sistemik bir unsura dönüştürmüştür. Başka bir ifade ile Washington'da alınan değişken dış politika kararları, ABD'nin sistem içindeki nispi pozisyonu nedeniyle pek çok bölgedeki ilişki kalıplarına şekil vermiştir.

Bu bölgelerden biri olan Ortadoğu'da ABD'nin askeri varlığı, Körfez savaşı, Afganistan savaşı ve 2003 Irak işgali gibi müdahalelerle kendini hissettirirken bölgesel güçler arasındaki rekabeti de sıfırlayıcı bir etki doğurmuştur. Soğuk Savaş sonrası bölgeye yönelik stratejisini müdahaleci bir yaklaşım üzerine temellendiren Washington yönetimi, 2010 y1lına gelindiğinde bu stratejinin doğurduğu maliyetlerden kurtulma kararı alarak yeni bir stratejiyi devreye sokmuştur. ${ }^{1}$

Devreye sokulan bu yeni strateji, devlet davranışlarının altında yatan kaygıyı, güç ve güvenlik maksimizasyonu üzerinden okuyan realist paradigma içerisinde üç farklı kavram üzerinden tartışılmaktadır. Bunlardan ilki, ABD'nin 2010 yılından itibaren Ortadoğu'daki askeri varlığını peyderpey azaltmasına ve kendine rakip olacak bir bölgesel hegemonun bölge ülkeleri tarafından dengeleneceği ön görüsüne dayanan "kıyıdan dengeleme" (Offshore Balancing) stratejisidir. ${ }^{2}$ Bu yaklaşım ABD’nin 2003 Irak işgalinin ağır faturasından ve bölgede artan terör sorununun doğrudan kendisini

1 "Başkan Obama'nın, Afganistan ve Pakistan'daki Durumun Geleceğine Dair Konuşması", ABD Diplomatik Temsilcilikler-Türkiye, 1 Aralık 2009, http://turkish. turkey.usembassy.gov/konusma_120109.html, (10 Ekim 2016).

2 John J. Mearsheimer, “A Return to Offshore Balancing”, Newsweek, 31 Aralik 2008, http://europe.newsweek.com/return-offshore-balancing-82925?rm=eu, (10 Ekim 2016), John J. Mearsheimer ve Stephen M. Walt, "The Case for Offshore Balancing”, Foreign Affairs, 13 Haziran 2016, https://www.foreignaffairs.com/articles/united-states/2016-06-13/case-offshore-balancing, (10 Ekim 2016). 
hedef almasından kaçınması gerektiğine vurgu yaparak karadaki birliklerin çekilmesiyle bu maliyetlerin azalacağını öne sürmektedir. Obama yönetiminin Irak ve Afganistan'dan ABD'nin askeri varlığını azaltma kararı almasını kıyıdan dengeleme stratejisinin önemli bir göstergesi olarak gören bu yaklaşım, yeni dönemde olası bir Amerikan müdahalesinin deniz ve hava kuvvetlerinin kullanımını içermekle birlikte bölgesel güç dengesinin bozulması durumunda gerçekleşmesinin gerekliliğine vurgu yapmaktadır.

İkincisi ise ABD'nin Ortadoğu'daki askeri varlığını, bölgesel aktörler arasındaki klasik güvenlik ikilemlerini sona erdiren ve hegemonik istikrar sağlayan bir garantör olarak görmekte ve çekilme kararını bölgede son dönemlerde karşılaşılan kriz alanlarının doğuşunda bir milat olarak tanımlamaktadır. ${ }^{3}$ Bu strateji değişikliğinin ardındaki gerekçeler müdahaleci dış politikanın sebep olduğu yüksek maliyetlere ve prestij kaybına bağlanmakta ve yeni strateji izolasyonizm kavramıyla açıklanmaktadır. Üçüncüsü ise diğer iki kavramsallaştırmada olduğu gibi Obama dönemi öncesinde Ortadoğu'ya yönelik izlenilen müdaheleci stratejilerin son dönemlerde meydana getirdiği ağır maliyetlere değinerek, yeni dönemde özellikle askeri alanda yapılan harcamalarda tasarrufa gidilmesini, ABD'nin Ortadoğu'daki kriz alanlarına geçmişe nazaran daha düşük düzeyde müdahil olmasını ve tehditlerle mücadelede bölgesel aktörlere daha fazla alan açmasını "mevzilenme" (retrenchment) kavramıyla açıklamaktadır. ${ }^{4}$

Aralarındaki kavramsal farklılığa rağmen bu üç yaklaşımın da değişimin temel parametrelerini oluşturan iki farklı realite konusunda mutabık kaldığ 1 söylenebilir. Bunlardan ilki, ABD'nin tekrar bir stratejik değişime gidene kadar bölgede meydana gelen krizlere müdahil olmayacağı ve bunların doğurduğu maliyetleri yerel aktörlere yükleyeceğidir. İkincisi ise bu strateji-

3 Hasan Basri Yalçın, “ABD, Suriye'de PKK Devleti Kuruyor”, Star, 27 Haziran 2016, http://haber.star.com.tr/yazar/suriyede-amerikaya-bagliliktan-cikmaliyiz-diyendr-hasan-basri-yalcin-uyariyor/yazi-1121292, (10 Ekim 2016). Bu bilgiler Fadime Özkan'ın gerçekleştirmiş olduğu mülakattan alınmıştır. Ayrıca bkz. Hasan Basri Yalçın, “Ortadoğu'da Yeni Durum ve Türkiye'nin D1ş Politika Stratejisi”, s. 15-18. Burhanettin Duran, Kemal İnat ve Ali Balc1, Türk Dış Politikası Yıllığı 2013, Ankara SETA Yayınları, 2014. Hasan Basri Yalçın, “Obama Stratejisi ve Ortadoğu” Akademik Ortadoğu, Cilt: 9, Say1: 2, 2015, s. 55-74.

4 Stephen G. Brooks, G. John Ikenberry ve William C. Wohlforth, "Don't Come Home America: The Case Against Retrenchment", International Security, Cilt: 37, Say1: 3, 2013, s.7-51, Kyle Haynes, “Decline and Devolution: The Sources of Strategic Military Retrenchment”, International Studies Quarterly, 2015. s. 490-502. 
nin bölgedeki mevcut güç dağılımında köklü bir değişime yol açacağı ve bölgesel sistemi devlet davranışlarının belirlenmesinde daha fazla ön plana çıkaracağıdır. Başka bir ifade ile Ortadoğu'daki yeni kriz alanları ve bu krizlere yönelik devlet davranışları, küresel sistemden nispeten bağımsız bir şekilde bölgesel sistemin sınırları içerisinde cereyan edecektir. ${ }^{5}$

Bu çalışma yukarıda kısaca değinilen sistemik değişimden yola çıkarak Ortadoğu'daki mevcut güç dağılımının, “Arap Baharı” sonrası bölgede çok sık rastlanan ve değişkenlik gösteren ittifakların ${ }^{6}$ altında yatan temel kayg1ya yönelik etkisini, isyan hareketinin uluslararası krizlere dönüştüğü Suriye örneği üzerinden araştırmak amacıyla kaleme alınmıştır.

$\mathrm{Bu}$ amaçtan hareketle çalışmada şu üç soruya cevap aranmaktadır; Ortadoğu'daki mevcut güç dağılımın doğurduğu sistemik özellikler nelerdir? Bu sistemik özellikler devletlerin ittifak stratejilerinde hangi motivasyonla hareket etmelerine yol açmaktadır? Bu sistemde devletler kaygılarını gidermek amacıyla ne tür stratejilere başvurmaktadır? Ayrıca çalışmada bahsi geçen sorulara cevap aranırken şu üç temel argüman sınanacaktır; birincisi Ortadoğu'da çatışma olasılığını arttıran mevcut güç dağılımı, devletleri güvenlik merkezli ittifak arayışlarına itmektedir. Sistemin sunduğu tercih zen-

Hans J. Morgenthau, Politics Among Nations: The Struggle for Power and Peace, New York: McGraw-Hill, 1993, s. 213-216, Küresel güç dağ1lımından bağımsız olarak bölgesel sistemlerin varlığı hakkında bkz; Nuno P. Monteiro, Theory of Unipolar Politics, New York: Cambridge, 2014, s. 171-173.

6 Teorisyenler tarafından çatışma ve mücadele bağlamında ele alınan ittifak kavramı, kapsam açısından ortak bir paydanın oluşmasına vesile olsa da üzerinde durulan örnek olayların farklılığından mütevellit bir takım nüanslar içermektedir. Bu nüanslara bir kaç isim üzerinden değinmek gerekirse, yaptığı çalışmalarla literature ciddi katkılar sağlayan Bruce M. Russett ittifak kavramını askeri güç kullanma koşullarıyla ilgilenen sınırlı sayıdaki devlet arasında gerçekleştirilen resmi anlaşmalar olarak tanımlamaktadır. Benzer şekilde Glenn H. Snyder ve Hans Morgenthau da ittifakları iki ya da daha fazla devlet arasında askeri konuları içeren ve yasal kodifikasyonlarla sınırları çizilen işbirlikleri olarak görmektedir. Bu isimlerden farklı olarak Stephen M. Walt ise gayr-i resmi anlaşmalara değinerek ittifakları, iki ya da daha fazla devlet arasında meydana gelen ve güvenlik konuları ile ilgili resmi veya gayr-i resmi taahhütler içeren işbirliği şeklinde tanımlamaktadır. Bu çalışmada ise Walt tanımını referans alınarak ittifakların tespiti yapılmaya çalışılacaktır. Kavramlara dair ayrıntılı bilgi için bkz: Bruce M. Russett, An Empirical Typology of International Military Alliances, Midwest Journal of Political Science, Cilt. 15, No. 2, (May1s 1971), s. 262-263., Glenn H. Snyder, Alliance Politics, Ithaca: Cornell University Press, 1997, s. 4., Morgenthau, s. 197., Stephen M. Walt, "Why Alliances Endure or Collapse", Survival: Global Politics and Strategy, Cilt. 39, No. 1, 1997, s. 157. 
ginliği güvenlik kaygılarının minimize etmek isteyen devletleri değişken ve bağlayıcılı̆̆ 1 olmayan ittifaklar kurmaya yönlendirmektedir. İkincisi, devletler güvenliklerini tehdit eden unsurlar olarak sadece diğer devletlerin sahip olduğu askeri kapasiteyi değil aynı zamanda bu kapasitenin tehdit derecesini belirleyen coğrafi yakınlık ve saldırgan niyetlere de odaklanmaktadır. Bu unsurlar Ortadoğu'daki mevcut güç dağılımının meydana getirdiği odaklanma problemlerini asgari seviyeye indirmektedir. Üçüncüsü, mevcut güç dağılımı, devletlerin temel kaygıyı gidermesi noktasında gerek onları ittifaklara dâhil eden gerekse tehdit algılarına rağmen ittifak dışı kalmalarına yol açan stratejik opsiyonlar sunmaktadır.

\section{Ortadoğu'daki Yeni Yapısal Özelliklerin Devlet Davranışlarına Etkisi}

Obama yönetiminin ABD'nin Ortadoğu stratejisinde değişime gitmesi bölgedeki aktörlerin davranışlarını şekillendiren yapısal sınırlar açısından bölgedeki mevcut güç dağılımını belirleyici bir konuma taşımıştır. Bu yapısal değişim ABD'nin bölgeyi domine ettiği hegomonik güç dağılımından Türkiye, Suudi Arabistan, İran, İsrail ve Misır gibi bölgesel aktörlerin daha aktif rol oynadıkları yeni bir sistemle neticelenmiştir. Obama doktrinin bir sonucu olarak bölgedeki krizlerde inisiyatif üstlenmeleri konusunda kendilerine alan açılan bu devletler, aralarındaki ilişki kalıplarını ise her biri bir kutbunu oluşturdukları yeni güç dağılımı içerisinde yeniden dizayn etme mecburiyetiyle yüzleşmişlerdir. Her ne kadar Obama doktrini, Rusya, Almanya, Fransa ve İngiltere gibi bölge dışındaki aktörlere Ortadoğu'nun kriz alanlarına (Suriye, Irak, Yemen, Libya) müdahale etme noktasında firsatlar sunsa da bu aktörlerin bölgeyi domine edebilecek güç kapasitesinden yoksun olması, Ortadoğu'nun çok kutuplu yapısında sistemik bir değişim meydana getirmemektedir. Dolayısıyla “Arap Baharı" sonrası kriz alanlarına bağlı olarak değişkenlik gösteren ittifakların anlamlandırılması, çok kutuplu bir güç dağılımı sergileyen bölgesel sistemin genel özelliklerinin tespitinden geçmektedir.

Güç unsurlar1 ${ }^{7}$ göz önüne alındığında en az üç ya da daha fazla aktör ta-

Güç içinde barındırdığı unsurlar ve amaçsallık-araçsallık tartışması açısından farklı paradigmalar nazarında farklı anlamlar içermektedir. Bu çalışma ise realist paradigmanın güç tanımından hareketle kapasite dağılımını ele alacak ve neorealistlerin yaklaşımını benimseyerek gücü amaçlar hiyerarşisine hizmet eden bir araç olarak değerlendirecektir. Bu noktadan hareketle çalışmada neo-realistlerin önde gelen 
rafından domine edilen bir küresel/bölgesel sistem olarak tanımlanan çok kutupluluk, devlet davranışlarını belirleyen dört temel özellik barındırmaktadır. ${ }^{8}$ Birincisi, çok kutuplu sistemin kapasite açısından yaklaşık olarak birbirine denk üç ya da daha fazla aktörden meydana gelmesi dost-düşman ayrımındaki belirsizliklerin artmasına yol açmaktadır. Sistemdeki belirsizlik Waltz'un ifadesiyle “... bir gücün müttefikler ile düşmanlar arasında net ve değişmez sınırlar çizmesine imkân vermeyecek kadar çok sayıda gücün" bulunmasından kaynaklanmaktadır. Sistemdeki büyük güçlerin say1sında yaşanacak artış hâlihazırda mevcut olanlar için odaklanma problemleri doğurmanın yanı sıra enformasyon süreci ve kaynak tahsisi açısından da bir takım problemler meydana getirmektedir. ${ }^{10}$

İkincisi, aktör sayısındaki artışa bağlı olarak çoğalan ilişki ağları ve etkileşim firsatları, aktör davranışlarına esneklik katmaktadır. Deutsch ve Singer tarafından " $\mathrm{n}(\mathrm{n}-1) / 2$ " olarak formülize edilen bu ilişki ağları, işbirliğine açık olduğu kadar rekabete de açı olmaktadır. ${ }^{11}$ Başka bir ifade ile sistemdeki bağımsız aktör sayısı (n) arttıkça etkileşim firsatlarının sayısı ve niteliği armaktadır. Daha önce değindiğimiz dost-düşman ayrımındaki belirsizlik de hesaba katıldığında çok kutuplu sistemde aktörler birbirlerine olan bağımlılıklarını minimize edecek firsatlar yakaladıklarından dolayı muhtemel krizler neticesinde ittifaklar kırılganlaşmaktadır. Üçüncüsü, çok kutuplu sistem rakiplerin birbirlerinin niyetlerini ve kapasitelerini yanlış hesaplama riskileri barındırmaktadır. Sistemdeki bir devletin odaklanması gereken aktör sayısı birden fazla olduğundan devletler bu kabiliyetlerinde gerileme yaşamaktadırlar. Bu durum provokasyon riskini arttırmakta ve örneğin iki aktör arasında kurulan bir savunma ittifakının diğerleri tarafından saldırgan olarak algılanmasına neden olmaktadır. ${ }^{12}$

isimlerinden Mearsheimer'ın güç tanımı referans alınacaktır. Mearsheimer'a göre güç örtülü ve askeri olmak üzere iki unsuru içinde barındırmaktadır. Örtülü güç, bir devletin askeri gücünü besleyen ekonomisini ve nüfusunu ifade etmektedir. Mearsheimer, The Tragedy of Great Power Politics, New York: Norton Company Inc, 2001, s. 55. Gücün ayrıntılı tanımı için ayrıca bkz: Morgenthau, s. 124-165.

8 Mearsheimer, The Tragedy of Great Power Politics, s. 337-338.

9 Kenneth Waltz, Uluslararası Politika Teorisi, çev: Osman S. Binatlı, Phoenix Yayınevi, Ankara, 2015, s. 209.

10 Karl W. Deutsch ve J. David Singer, "Multipolar Power Systems and International Stability”, World Politics, Cilt.16, No.3, 1964, s. 396.

11 Deutsch ve Singer, s.392-393.

12 Snyder, s. 145-146. 
Çok kutuplu sistemde meydana gelen güç dağılımının neden olduğu son özellik ise sistemindeki çatışma olasılığının yüksek olmasıdır. Çatışma olasıllğı diğer özelliklerin doğal bir çıktısı olarak değerlendirilebilir. Zira aktör sayısındaki artış etkileşim firsatlarını çoğaltan bir etki doğurduğu gibi çatışma risklerini de yükselten bir etki doğurmaktadır. Yani iki aktörün $(\mathrm{A}, \mathrm{B})$ bulunduğu bir sistemde muhtemel çatışma (A-B) bunlar arasında cereyan edecek iken üç aktörün (A-B-C) bulunduğu bir sistemde en az üç farklı çatışma (A-B, A-C, B-C) meydana gelebilmektedir. Sistemdeki güç dağılımının zayıf aktörlere sağladığı geniş politik manevra alanları hesaba katıldığında çatışma olasılı̆̆ının daha da attığı gözlemlenmektedir. Zira sistem sadece majör-majör değil aynı zamanda majör-minör ve minör-minör mücadelelerine tanıklık edilebilmektedir. ${ }^{13}$

Netice itibariyle gerek dost-düşman ayrımında belirsizliklere yol açması gerekse yanlış hesaplama riski ve çatışma olasılı̆̆ının artması gibi kriz alanlarının doğuşuna zemin hazırlayan özellikler barındırdan çok kutuplu sistem, sahip olduğu anarşik yapısıyla devletlerin amaçlar hiyerarşisinin yeniden dizayn edilmesini gerekli kılmaktadır. Çok kutuplu güç dağılımının oluşturduğu odaklanma problemleri, devletleri en ulvi amaçları olan varlıklarını sürdürme dürtüsüyle hareket etmeye sevk etmekte ve bu amacı gerçekleştirmenin araçlarından biri olan savunmacı ittifaklara yönlendirmektedir. ${ }^{14}$

\subsection{Güvenlik Merkezli Kaygı: Tehdit Dengesi (Balance of Threat)}

Başlıca amacı varlığını sürdürmek olan devletlerden müteşekkil uluslararas1 sistemde aktörler, diğerlerinin davranışlarına kuşkuyla yaklaşmaktadırlar. Bir devlet herhangi bir nedenle kapasitesini arttırmanın yollarına başvurduğu takdirde niyetlerin bilinememesi ve uluslararası sistemde saldırgan niyetlere sahip olanları cezalandıracak bir üst otoritenin bulunamaması nedeniyle diğerleri tarafından davranışları tehdit olarak algılanmaktadır. $\mathrm{Bu}$ şartlar altında belirli bir askeri kapasiteye sahip olan devletler, rasyonel davranarak tehdidi engellemenin yolların arayacaklardır. ${ }^{15}$ Neo-realistlerin hemfikir oldukları bu tabloda devletler ya mevcut kapasitelerini kullanarak

13 Mearsheimer, Back to the Future, International Security, Cilt. 15, No. 1, (Yaz 1990), s. 14.

14 Waltz, Uluslararası Politika Teorisi, s.129, s. 142.

15 Mearsheimer, The Tragedy of Great Power Politics, s. 30-32. 
ya da ittifak kurarak güvenliklerini sağlayacaklardır.

The Origins of Alliances adlı eserinde, devletlerin güvenlik merkezli temel kaygısını ortadan kaldırmanın bir aracı olarak savunmacı ittifaklara yönelişini ele alan Stephen M. Walt, devletlerin ittifak stratejilerinde tehdit hiyerarşisinin belirleyici olduğunu öne sürmektedir. Walt'a göre, tehdit derecesi yüksek olan zayıf devlete karşı tehdit algılayan devlet güçlü bir devletle ittifak kurabilir. Başka bir ifade ile devletler anarşik bir sistemin doğurduğu güvenlik problemlerini, muhtemel tehditlerin sadece askeri ve ekonomik kapasitesine değil aynı zamanda bu kapasitelerin mobilizasyonunu etkileyen ve kullanım amaçlarını vurgulayan ilave unsurları da dikkate alarak tanımlamaktadırlar. ${ }^{16}$

Walt, klasik güç merkezli yaklaşımlardan farklı olarak bu unsurları dört başlık altında incelemektedir. Bunlardan ilki, devletlerin sahip olduğu toplam güçtür (aggregate power). Walt toplam gücün devletlerin nüfusunu, askeri kapasitesini, endüstrileşme ve teknolojik gelişmişlik seviyesini kapsayan materyal verilerden oluştuğunu belirtmektedir. Walt'a göre, devletler toplam güç ile düşmanlarını cezalandırıp dostlarını da ödüllendirebileceğinden toplam güç tehdidin en önemli bileşenleri arasında yerini almaktadır. Tehdit derecesinde belirleyici olan ikinci faktör ise saldırı gücüdür (offensive power). Walt'a göre bir devletin saldırı gücü diğer devletleri provoke eden ve askeri kapasiteyi ifade eden bir unsurdur. $\mathrm{Bu}$ güç devletlerin doğrudan egemenliklerini ve toprak bütünlüklerini tehdit etmektedir. Bu nedenle saldırı gücü diğer devletleri dengeleme stratejisi uygulamaya itmektedir. ${ }^{17}$

Tehdidin derecesini belirleyen üçüncü faktör coğrafi yakınlıktır (geographic proximity). Walt'a göre tehdit seviyesini belirleyen diğer şartlar eşit olduğunda birden fazla devletten tehdit algilayan aktör önceliğini coğrafi yakınlığı bulunana verecektir. ${ }^{18}$ Toplam güç gibi coğrafi yakınlığın da devletlerin izleyeceği ittifak stratejisinde belirleyici olacağını öne süren Walt devletlerin toplam gücü nispeten fazla olan tehditten ziyade coğrafi yakınlığ 1 bulunan tehdide karşı daha hassas olduğunu savunmaktadır. ${ }^{19}$ Tehdit derecesinde belirleyici olan dördüncü faktör ise saldırgan niyetlerdir (aggressive intentions). Walt bir devletin saldırgan tavırlar sergilemesini diğer-

\footnotetext{
16 Walt, The Origins of Alliances, New York: Cornell University Press, 1990, s. 17.

17 Ibid., s. 24-25.

18 Ibid., s. 23-24

19 Ibid., s. 158.
} 
lerini provoke edecek bir unsur olarak görmektedir. Walt'a göre saldırgan niyetler saldırganla kurulacak bir ittifakla dahi giderilemiyorsa savunmasız devletler için onu dengelemekten başka bir seçenek bulunmamaktadır. ${ }^{20}$

The Origins of Alliances adlı kitabında 1955-1979 yılları arasında Ortadogu'da kurulan savunmacı ittifaklardan hareketle "tehdit dengesi" kavramını literature kazandıran Walt, dönemin iki kutuplu küresel sisteminin Ortadoğu'ya olan etkisi işı̆̆ında devletlerin tehditlerle mücadele stratejilerine değinmektedir. Bu noktadan hareketle Walt, devletlerin "peşine takılma" (bandwagoning) stratejisinden ziyade dengeleme (balancing) stratejisi izlemeye meyilli olduğunu vurgulamaktadır. Fakat gerek küresel sistemdeki güç dağılımının Soğuk Savaş'ın sona ermesiyle birlikte değişime uğraması gerekse Obama doktrinin neticesinde Ortadoğu'daki bölgesel güç dağıl1mın devletlerin davranışlarındaki etkisini arttırması, yeni sistemik sınırlar içerisinde tehditle mücadele stratejilerinin yeniden belirlenmesi zaruriyetini doğurmaktadır.

\section{2. Çok Kutuplu Sistemde Tehditlerle Mücadele Stratejileri}

Bir sistemdeki güç dağılımı o sistemdeki devletlerin mevcut veya müstakbel tehditlerle mücadelesinde belirleyici bir rol oynamaktadır. Çok kutuplu güç dağılımının bir sonucu olarak tehditlerin çoğaldığı, belirsizliğin hâkim olduğu ve ilişki ağlarının esnekliğe sahip olduğu bir sistemde devletlerin tehditlerle mücadelede hangi stratejileri izleyebileceği sorusuna cevap aramak önem arz etmektedir. Sistemin sabit unsuru olan anarşi ile değişken unsur olan güç dağılımı birlikte düşünüldüğünde üç ya da daha fazla büyük devletin ve belirli sayıdaki küçük devletin yer aldığı bir sistemde tehditlerle mücadele için üç farklı stratejik opsiyonun varlığından söz edilebilir. ${ }^{21}$

Bunlardan ilki, bir devlet veya bir ittifakın sistemdeki diğer devlet veya ittifakları askeri ve/veya politik üstünlük açısından tehdit etmesine karşılık olarak tehdit edilen devletin ya kendi kaynakların devreye sokarak ya da tehdit algılayan diğer devletlerle ittifak kurarak tehdidi caydırması anlamına gelen dengeleme stratejisidir. ${ }^{22}$ Realist paradigma içerisinde genel

$20 \quad$ Ibid., s. 25-26.

21 Schweller, Deadly Imbalance: Tripolarity and Hitler's Strategy of World Conquest, New York: Columbia University Press, 1998, s. 65-67.

22 Schweller, Unanswered Threats: Political Constraints on the Balance of Power, New Jersey: Princeton University Press, 2006, s. 9. Dengeleme stratejisinin geleneksel 
kabul gören bu tanımdan da anlaşılacağı gibi dengeleme, tehdit unsurlarından hareketle bir aktörün diğerlerinin kısa veya uzun vadede varlıklarını tehlikeye atacak davranışlarda bulunmasına karşılık tehdit algılayanlar tarafindan verilen bir cevap niteliğindedir. Bu cevap bir devletin kendi kapasitesini arttırarak tehdidi davranışlarında vazgeçirmesi anlamına gelen "dahili dengeleme" şeklinde olabileceği gibi müşterek tehdit algılarına sahip olan devletlerle işbirliğini tercih ederek tehdidi engellemeyi ifade eden "harici dengeleme" şeklinde de olabilir. ${ }^{23}$ Tehdit olma potansiyeline sahip en az üç devletin bulunması, ittifak ilişkilerinin esnekliğe sahip olması ve sistemin küçük devletlere manevra alanı sunması gibi çok kutuplu sistemin özellikleri dikkate alındığında ittifaklar vasıtasıyla sağlanacak dengeleme stratejilerinin olasılığının arttığı söylenebilir.

İkincisi, dengeleme stratejisinin zıttı olarak okunabilecek peşine takılma stratejidir. Bu strateji engellenemeyen tehdit ile ittifak kurma anlamina gelmekte ve "kaybedenler açısından dahi kazançların mümkün olduğu ve kaybetmenin bunların güvenliğini tehlikeye sokmadığ 1 bir durumda" ${ }^{24}$ izlenilebilecek makul bir stratejidir. Kaybedenlerin stratejisi olarak tanımlayabileceğimiz peşine takılma stratejisi, tehdidin üstünlügünü kabul etme açısından bir yenilgi anlamı taşısa da üstünlüğün sağlayacağı güvelik şemsiyesi altına girme açısından varlığını sürdürmenin teminatı olarak okunabilir. Peşine takılma stratejisi her ne kadar devletlerin bireysel veya kolektif olarak tehdidi caydırabilecek askeri kapasiteye ve bu kapasiteyi destekleyecek ekonomik güce sahip olmamalarından kaynaklansa da çok kutuplu sistemin zayıf devletlere sunduğu politik manevra alanları hesaba katıldığında bu stratejinin uygulanabilirliği azalmaktadır. Sistemdeki güçlü aktör sayısı arttıkça zayıf devletler tercih imkânları elde etmekte ve dengeleme veya sorumluluğu başkasına yükleme firsatları kazanmaktadırlar.

Çok kutuplu sistemde tehditlerle mücadelede uygulanabilecek üçüncü stratejik opsiyon ise "sorumluluğu başkasına yükleme"dir (buck-passing). Bu strateji dengeleme ve peşine takılma stratejisinin aksine ittifaklardan uzak durmayı ifade etmektedir. Tehdit algılayan devletlere sistemdeki aktörlere tehditlerle yüzleşmenin maliyetlerinden kaçınma, nispi pozisyonlarını

kullanımı için ayrıca bkz: Walt, The Origins of Alliance Politics, s. 18-19.

23 Mearsheimer, The Tragedy of Great Power Politics, s. 156-157.

24 Waltz, Uluslararası Politika Teorisi, s. 158. 
koruma ve geliştirme olanakları sunmaktadır. ${ }^{25}$ Çok kutuplu sistem olas1 bir tehdidi engelleyecek çok sayıda aktörü içinde barındırdığından dolayı sorumluluğu başkasına yükleme stratejisinin uygulanmasına imkân tanımaktadır. Bu strateji, birden fazla tehdit ile karşı karşıya kalan aktörler için cazip olmakla birlikte ittifakların kırılganlaşmasını sağlayan riskleri de içinde barındırmaktadır. ${ }^{26}$

\section{Tehdit Dengesi Perspektifinden Suriye Krizi}

\section{1. İttifakların Kuruluş Serüveni Bağlamında Suriye Krizi}

17 Mart 2011'de Suriye'nin genelinde muhalifler tarafından gerçekleştirilen sivil gösteriler, ilk kez Der'a'da ordunun sivillere yönelik silah kullanmas1 ile birlikte yerini şiddetli çatışmara bırakmış ve Suriye rejim ile muhalifler arasında cereyan eden iç savaş sarmalına sürüklenmiştir. Taraflar arasındaki çatışma yoğunluğunu arttırdıkça özellikle bölgesel aktörler sorunun bir parçası haline gelmiş ve yereldeki aktörlere sunulan askeri destek kapsamında iki farklı ittifak meydana gelmiştir. Bu ittifaklardan ilki, isyan hareketlerinin Suriye'ye sıçramasıyla birlikte müşterek tehdit algısı kapsamında Suriye rejimiyle ikili ilişkileri 1980'lere dayanan İran ile 1950'lerden buyana rejimle stratejik ilişkilere sahip olan Rusya arasında inşa edilmiştir. Her iki ülke de krizin erken dönemlerinde rejime olan askeri desteklerini farklı araçlar kullanarak sağlasalar da 2015 yazı itibariyle somut bir ittifak çerçevesinde birlikte hareket ederek birbirini tamamlayan ve organize bir destek sunmuşlardır. İkincisi ise çatışmaların başladığg ilk günden itibaren muhaliflerin direncini korumasında büyük bir paya sahip olan Türkiye, Katar ve Suudi Arabistan arasında kurulmuştur. Yaklaşım farklılıkları olmakla birlikte, bu ülkeler diyalog girişimlerinin sonuçsuz kaldığ 2012 yılının başlarından itibaren müşterek askeri politikalar üzerinden gayr-i resmi ittifak kurarak krizin belirleyici aktörleri arasında yer almışlardır.

Sırasıyla bu ittifakların sahadaki müttefiklerine olan askeri yardımlarına değinecek olursak rejim açısından en önemli müttefiklerden birinin İran olduğu söylenebilir. İran'ın rejime olan askeri desteği İran-Rusya ittifakının somutlaşmaya başladığı son dönem öncesinde iki kanal üzerinden ger-

25 Thomas J. Christensen ve Jack Snyder, Chain Gang and Passed Bucks: Predicting Alliance Patterns in Multipolarity, International Organization, Cilt. 44, No. 2, (İlkbahar 1990), s. 141.

26 Mearsheimer, The Tragedy of Great Power Politics, s. 159-162. 
çekleşmiştir. Bunlardan ilki, toplumsal gösterilerin bastırılmasına ve Suriye Ordusu'nun eğitimine katkı sağlayacak uzman desteğinin sağlanması diğeri ise Suriye Ordusu saflarında savaşacak yabancı unsurların eğitimi ve donanımının üstlenilerek organize edilmesidir. Toplumsal gösterilerin kontrollü bir biçimde bastırılmasını 2009 yılında tecrübe edinen İran, Suriye'deki halk hareketinin sivil bir görünüm sergilediği erken dönemde Suriye rejimine askeri danışmanlar göndermiştir. ${ }^{27}$

İran menşeli bu önleyici müdahale anlayışı nedeniyle silahlı çatışmaların yoğunluğunu arttırması ve ülke geneline yayılması Tahran yönetimini askeri yardımların dozunu arttırma kararı almaya itmiştir. Özellikle karşı ittifakın muhaliflere silah yardımları yapmasıyla birlikte Suriye'deki varlığ 1 tehlikeye giren İran, bölgedeki nüfuzunu kullanarak çok sayıda yabancı savaşçının Suriye'ye gelmesinde etkili olmuştur. Bu bağlamda Irak merkezli Asaib Ehlülhak, Kataib Hizbullah ve Kataib Seyyid eş-Şuheda adlı milis güçleri Liva Ebu Fadlül Abbas adlı çatı oluşum altında bir araya getiren İran, bu milislerin eğitiminde ve Suriye'ye sevkinde rol oynamıştır. ${ }^{28}$ Tahran yönetiminin Suriye Ordusu'na sağladığı yabancı savaşçı desteğinin d1şında doğrudan İran güvenlik birimlerinin Suriye'deki varlığı da bilinmekte ve resmi ağızlardan kabul edilmektedir. İran Devrim Muhafızları (IDM) Komutanı Muhammed Ali Caferi yaptığı açıklamada İDM'ye bağlı Kudüs Gücü'nün Suriye'de rejim saflarında savaştı̆̆ını, Suriye Ordusu'nun eğitiminde ve yabancı savaşçılardan oluşan milislerin kuruluşundan cepheye varıncaya kadar tüm süreçlerinde aktif rol üstlendiğini kabul etmiştir. ${ }^{29}$

Sağladığı askeri yardımlarla Suriye rejiminin varlığını sürdürmesinde etkili olan aktörlerden bir diğeri ise Rusya'dır. Krizin erken dönemlerinde Suriye'ye yapılan askeri sevkiyatları rejimle arasındaki askeri anlaşmalara bağlayan Moskova yönetimi yaptığı açıklamada anlaşmalara bağlı kalacağını

27 Adam Entous ve Matthew Rosenberg, "U.S says Iran helps crackdown in Syria", The Wall Street Journal, 14 Nisan 2011, http://www.wsj.com/articles/SB100014240527487 04547804576261222747330438, (20 Kasim 2016).

28 Michael Knights, "Iran's Foreign Legion: The Role of Iraqi Shiite Militias in Syria", The Washington Institute for Near East Policy, 27 Haziran 2013, http://www. washingtoninstitute.org/policy-analysis/view/irans-foreign-legion-the-role-of-iraqishiite-militias-in-syria, (20 Kasım 2016).

29 Farnaz Fassihi ve Jay Solomon, “Top Iranian Official Acknowledges Syria Role”, The Wall Street Journal, 16 Eylül 2012, http://www.wsj.com/articles/SB10000872396390443720204578000482831419570, (20 Kasım 2016). 
ve gerekli yükümlülükleri yerine getireceğini ilan etmiştir. ${ }^{30} \mathrm{Bu}$ bağlamda BMGK' da sunulan ve Suriye'ye silah ambargosunu içeren karar tasarılarını veto eden Rusya, krizin yoğunluğunu arttırmasıyla birlikte rejime verdiği askeri desteğin dozunu arttırmıştır. Moskova yönetimi özellikle Suriye'ye yönelik askeri operasyonların uluslararası kamuoyunda tartışılmaya başlandığ 2012 yılı itibariyle havadan ve denizden gelebilecek saldırılara karşı Suriye'nin savunma sistemini güçlendirecek çok sayıda mühimmatı bölgeye sevk etmiştir. ${ }^{31}$

Rusya ve İran'ın müşterek askeri desteğine rağmen 2014 yılının son çeyreğinde muhaliflerin İdlib'i alarak Lazkiye'ye doğru ilerlemesi ve Esad'ın Türkiye, Katar ve Suudi Arabistan gibi ülkeler tarafından desteklenen muhalifler karşısında ordunun ülkeyi savunacak gücü kalmadığını açıklaması İran-Rusya hattında rejimin geleceği konusunda kaygıların artmasına neden olmuştur. Bu gelişmelerin ardından Moskova'ya bir ziyaret gerçekleştiren İDM'nin özel birlikleri olan Kudüs Gücü’nün komutanı Kasım Süleymani Putin ile bir görüşme gerçekleştirmiştir. Yapılan görüşmede Rusya ve İran'ın muhaliflere yönelik koordineli bir operasyon planı masaya yatırılmiştır. ${ }^{32}$

$\mathrm{Bu}$ görüşeme trafiğinin ardından rejimle masaya oturan Moskova yönetimi, 1980 ve 1994 'teki askeri anlaşmalara ilaveten Lazkiye' de bir askeri üs (Himeymim) kurması kararlaştıran yeni bir anlaşma imzalamıştır. ${ }^{33}$ Yeni anlaşmanın ardından bölgedeki askeri varlığında ciddi bir artışa giden Rusya, Ağustos 2015 itibariyle çok sayıda savaş gemisini Türk boğazlarından geçirerek Lazkiye' de kurulan üsse asker ve mühimmat sevk etmiştir. ${ }^{34}$ Bir yıla

30 "Russia dismisses uproar over Syria arms sales", Raw Story, 17 May1s 2013, http:// www.rawstory.com/2013/05/russia-dismisses-uproar-over-syria-arms-sales/, (20 Kasim 2016).

31 Adrian Blomfield, "Russian arms ship to make second attempt to deliver helicopters to Syria", The Telegraph, 24 Haziran 2012,

http://www.telegraph.co.uk/news/worldnews/middleeast/syria/9352852/Russian-armsship-to-make-second-attempt-to-deliver-helicopters-to-Syria.html, (20 Kasim 2016).

32 Laila Bassam ve Tom Perry, "How Iranian general plotted out Syrian assault in Moscow", Reuters, 6 Ekim 2015, http://www.reuters.com/article/us-mideast-crisissyria-soleimani-insigh-idUSKCN0S02BV20151006, (20 Kasim 2016).

33 Michael Birnbaum, "The secret pact between Russia and Syria that gives Moscow carte blanche", The Washington Post, 15 Ocak 2016, https://www.washingtonpost.com/ news/worldviews/wp/2016/01/15/the-secret-pact-between-russia-and-syria-that-givesmoscow-carte-blanche/, (20 Kasim 2016).

34 Tom Coghlan ve Michael Evans, "Russia sends men and arms to prop up dying Assad 
yakın bir hazılık sürecinin ardından Rusya-İran ittifak1 30 Eylül 2015'te harekete geçerek Lazkiye, İdlib, Hama, Humus, Halep, Şam ve Dera'daki muhalif unsurlara yönelik operasyonlar başlatmıştır.

Suriye krizinin askeri bir boyut kazanmasının ardından sahadaki muhalif unsurların askeri açıdan desteklenmesinde aktif rol oynayan devletler ise Türkiye, Katar ve Suudi Arabistan'dır. Rusya-İran ittifakının karşı ittifakını oluşturan bu devletler arasındaki askeri işbirliği iki farklı veri üzerinden ortaya konabilir. Bunlardan ilki ittifak içi ülkeler arasındaki askeri hareketliliğe dair iddialardır. İddalara göre bu hareketlilik Türkiye'nin koordinasyonunu üstlendiği, Katar ve Suudi Arabistan'ın da gerekli ekonomik destek verdiği bir silahlandırma sürecini içermektedir. $\mathrm{Bu}$ bağlamda muhaliflere sağlanacak her türlü askeri yardımın verimliliğini arttırmak amacıyla Adana'da askeri komuta merkezinin kurulduğ ${ }^{35}$ ve başta Ankara'daki Esenboğa havaalanı olmak üzere farklı noktalara 2012 yılı boyunca Katar ve Suudi Arabistan askeri kargo uçaklarının 160 farklı iniş gerçekleştirdiği öne sürülmüştür. Hava trafik verilerine dayandırılan bu bilgilere göre Katar hava kuvvetlerine ait C-17 ve Suudi Arabistan hava kuvvetlerine ait C-130 tipi askeri kargo uçakların Türkiye'ye gelerek askeri mühimmat sevkiyatında önemli görevler üstlenmişlerdir. ${ }^{36}$ Türkiye'ye ulaştırılan bu mühimmatların Cilvegözü sınır kapısından geçirilerek Halep ve İdlib'deki muhaliflere ulaştırıldığı dile getirilen iddialar arasında yer almaktadır.

İkincisi ise Suriye'de rejim karşıtı muhalif gruplar tarafından yapıldığı öne sürülen ve karşı ittifak tarafindan bu grupların askeri açıdan desteklendiğine dair veri olarak kullanılan iddialardır. Muhalifler tarafından yapıldığ 1 öne sürülen açılamalarda karşı ittifakın üyeleri askeri destek bağlamında açıkça ifade edilmiştir. Bu açıklamalardan bir kaçına değinecek olursak, ÖSO gruplarından biri olan General İdris'in komuta ettiği birliklerin sözcüsü Ahmed Ebu Rishan, Ürdün sınırı üzerinden Suudi Arabistan'ın kendi-

regime in Syria", The Weekend Australian, 3 Eylül 2015, http://www.theaustralian.com. $\mathrm{au} /$ news/world/the-times/russia-sends-men-and-arms-to-prop-up-dying-assad-regimein-syria/news-story/a3440914d5368896ac75603993c04099?=, (20 Kasim 2016).

35 Regan Doherty ve Amena Bakr, "Exclusive: Secret Turkish nerve center leads aid to Syria rebels", Reuters, 27 Temmuz 2012, http://www.reuters.com/article/us-syria-crisiscentre-idUSBRE86Q0JM20120727, (20 Kasim 2016).

36 C. J. Chivers ve Eric Schmitt, "Arms Airlift to Syria Rebels Expands, With Aid From C.I.A”, The New York Times, 24 Mart 2013, http://www.nytimes.com/2013/03/25/world/ middleeast/arms-airlift-to-syrian-rebels-expands-with-cia-aid.html?_r=0, $\quad(20 \mathrm{Kasim}$ 2016). 
lerine tanksavar gönderdiğgi ${ }^{37}$, Suriye'deki İhvan'1n yönetim komitesinden Muhammed el-Dorbi'nin Katar ve Suudi Arabistan tarafindan komşu ülkelere sağlanan paralarla muhaliflerin silahlandırıldı ${ }^{38}{ }^{38}$ ve Doha'da muhaliflerin örgütlü bir yapıya kavuşturulması girişimleri sonrası muhaliflerin silah yardımının Türkiye üzerinden merkezileştiği yönündeki iddialar ${ }^{39}$ her ne kadar Türkiye, Katar ve Suudi Arabistan gibi ismi zikredilen devletler tarafından doğrulanmasa da bu aktörler arasında gayr-i resmi bir ittifakın var olduğuna dair yapılan çalışmalarda referans olarak gösterilmektedir.

Muhaliflerden yapılan açıklamalara benzer bir şekilde Rusya-İran ittifakının Suriye'ye doğrudan müdahele etmesinin ardından karşı ittifakın üyeleri de Suriye krizindeki pozisyonlarını açıkça dile getirmişdir. Bu açıklamalardan bir kaçına değinmek gerekirse, karşı ittifakın üyelerinden Suudi Arabistan'ın Dışileri Bakanı Adil Cübeyr verdiği bir mülakatta 'Karadan havaya füze temininin Suriye'deki güç dengesini değiştireceğini düşünüyoruz. Bu füzeler 1lımlı muhalefete, rejimin kimyasal saldırılarda ve hava saldırılarında kullandığı helikopter ve uçaklarını devre dışı bırakma firsatı verir. Karadan havaya füzeleri, Suriye'deki güç dengesini değiştirir, tıpk1 daha önce Afganistan'da değiştirdiği gibi" diyerek muhalefetin silahland1rılmasındaki rollerini açıkça ortaya koymuştur. ${ }^{40}$

\subsection{Tehdit Algısının Boyutları Bağlamında Suriye Krizi}

Anarşik uluslararası sistemde en temel amacı varlığını sürdürmek olan devletler, bu amaca hizmet eden ittifakları tehdit algısının boyutlarına göre şekillendirmektedirler. Tehdit dengesi perspektifine göre bu algının boyutları tehdidin sahip olduğu askeri ve ekonomik kapasite, coğrafi yakınlık ve

37 Anne Bernard, "Syrian Rebels Say Saudi Arabia Is Stepping Up Weapons Deliveries", The New York Times, 12 Eylül 2013, http://www.nytimes.com/2013/09/13/world/ middleeast/syrian-rebels-say-saudi-arabia-is-stepping-up-weapons-deliveries.html, (20 Kasim 2016).

38 Karen DeYoung ve Liz Sly, "Syrian rebels get influx of arms with gulf neighbors' money, U.S. coordination", The Washington Post, 15 May1s 2012, https://www.washingtonpost. com/world/national-security/syrian-rebels-get-influx-of-arms-with-gulf-neighborsmoney-us-coordination/2012/05/15/gIQAds2TSU_story.html, (20 Kasim 2016).

39 Amena Bakr ve Mariam Karouny, "Qatar, allies tighten coordination of arms flows to Syria”, Reuters, 14 May1s 2013, http://www.reuters.com/article/us-syria-qatar-supportidUSBRE94D0GT20130514, (20 Kasim 2016).

40 "Muhalefete karadan havaya füze", Aljazeera Turk, 20 Şubat 2016, http://www.aljazeera. com.tr/haber/muhalefete-karadan-havaya-fuze, (20 Kasım 2016). 
davranışlarının bir çıktısı olan saldırgan niyetler tarafından belirlenmektedir. Suriye krizi bu perspektifle incelemeye tabi tutulduğunda her iki ittifak üyelerinin ortak tehdit algısında bir artışın meydana geldiği ve bu artışın devletleri ittifaklar kurmaya yönelttiği ifade edilebilir. Rusya-İran ittifakı rejimi ortadan kaldırma girişimlerini kendisi için bir tehdit olarak görürken Türkiye-Katar-Suudi Arabistan ittifakı ise değişimin engellenme girişimlerini ve bu amaçla uygulanan yöntemleri kendileri açısından tehdit olarak yorumlamıştır. Her iki ittifak da kendi içerisinde müşterek tehdit algısını barındırmakla birlikte üyelerin sahip olduğu ekonomik, askeri ve coğrafi farklılıklar tehdit algısının boyutlarında çeşitlilik meydana getirmektedir. $\mathrm{Bu}$ nedenle her bir aktör açısından Suriye krizinin doğurduğu tehdide ayrı ayrı değinmek gerekmektedir.

Suriye rejiminin varlığını sürdürmesini kendi güvenliği açısından olmazsa olmaz gören İran, Suriye krizini ulusal güvenliğinde önemli rol oynayan "direniş ekseninin" sona erdirilmesi için başlatılan bir "proje" şeklinde tanımlamaktadır. ${ }^{41}$ Karşı ittifakın üyelerinin bu "projenin" hayata geçirilmesinde başrol oynadığını öne süren Tahran yönetimi, rejim karşıtı politikalar neticesinde saldırgan niyetlere sahip bu ülkelerin bölgedeki askeri varlıklarını genişlettiğini iddia etmektedir. Bu bağlamda Katar ve Suudi Arabistan'1 Suriye'deki silahlı çatışmaların müsebbibi olarak gören İran, Türkiye'yi ise "Osmanlı" hayali peşinde koşan "revizyonist ve saldırgan" bir devlet şeklinde tanımlamaktadır. ${ }^{42}$ Bir röportajında İran'ın tehdit algısının boyutlarına ayrıntısıyla değinen Ali Hamaney'in dış politika danışmanı Ali Ekber Velayeti, Suriye'de yaşananların bölgesel güvenliği tehdit eden bir krize dönüşmesinde Türkiye, Katar ve Suudi Arabistan'ın muhalifler üzerinden bölgedeki askeri varlığını genişletmesinin önemli rol oynadığını belirtmiş ve bu revizyonist yaklaşımların ardındaki saldırgan niyetlerin doğrudan İran'ı güvenliğini hedef aldığını dile getirmiştir. ${ }^{43}$

Suriye rejiminin varlığını sürdürmesini kendi güvenliğinin bir parçası

${ }^{41}$ Bayram Sinkaya, “Arap Baharı Sürecinde İran'ın Suriye Politikası”, Siyaset, Ekonomi ve Toplum Araştırmalarl Vakfi, Nisan 2012, No. 53, http://arsiv.setav.org/public/ HaberDetay.aspx?Dil=tr\&hid=117082\&q=arap-bahari-surecinde-iran-in-suriyepolitikasi, s.8-10.

42 “İran: “Türkiye 'Yeni Osmanlıcıllk' peşinde”, Hürriyet, 12 Ekim 2012, http://www. hurriyet.com.tr/iran-turkiye-yeni-osmanlicilik-pesinde-27370399, (20 Kasim 2016).

43 “Assad's overthrow "red line" for Iran: supreme leader's aide", Reuters, 20 Ocak 2013, http://www.reuters.com/article/us-syria-crisis-iran-idUSBRE90J08320130120, Kasim 2016). 
olarak gören bir başka ülke ise Rusya'dır. Sovyet toprakları dışındaki tek askeri üssü Suriye'de bulunan Rusya, Suriye rejimiyle kurduğu güvenlik merkezli ilişkilerin olası bir rejim değişikliğiyle sona ereceği ve bölgede giderek artan "terör" sorunun bölgeye olan coğrafi yakınlığı nedeniyle kendi topraklarını sıçrayabileceği endişesi yaşamaktadır. ${ }^{44}$ Rusya'nın Suriye merkezli güvenlik yaklaşımının iki temel parametresini oluşturan bu unsurların dolaylı olarak karşı ittifak tarafından üretildiği göz önünde bulundurulduğunda Moskova yönetiminin tehdit algisında Türkiye, Katar ve Suudi Arabistan'ın bölgede artan askeri varlığı ve bu varlığın ardında yatan saldırgan niyetlerin etkili olduğu söylenebilir. Özellikle Türkiye'nin sınır ihlali gerekçesiyle Kasım 2015'te bir Rus savaş uçağını düşürmesinin ardından yaşanan hadiseyi güvenliğine yönelik saldırgan niyetlerin askeri tezahürü şeklinde tanımlayan Rusya, bölgeye çok sayıda S-400 bataryaları yerleştirerek savunmacı yaklaşım ortaya koymuştur. ${ }^{45}$

Devrimlerin doğurduğu rekabet ortamının devletlerin tehdit algılarında artışın meydana getirdiği gerçeğini göz önünde bulundurulduğunda, bu rekabete dahil olan Türkiye-Katar-Suudi Arabistan ittifakının müşterek tehdit algısının sonucunda kurulduğu öne sürülebilir. Fakat bu algı her üyenin sahip olduğu nispi pozisyon nedeniyle farklı boyutlarda yaşanmaktadır. Sırasıyla bu aktörlerin tehdit algılarının boyutlarına değinmek gerekirse Türkiye, krizin başlangıcından günümüze rejime verdiği askeri destekle gündeme gelen İran-Rusya ittifakının, bölgedeki askeri varlıklarını arttırmasından ve zaman zaman Türkiye'ye yönelik saldırgan davranışlar sergilemesini tehdit olarak algılamıştır. Her iki aktörün de bölgeye askeri mühimmat sevkiyatını engellemeye çalışan Türkiye, Moskova-Şam seferi yapan Rus uçağ ${ }^{46}$ ile Türkiye hava sahasını kullanan ve rotası Halep olan İran kargo uçağını ${ }^{47}$ zorunlu inişe tabi tutarak denetlemiştir. Her iki uçaktan da askeri mühim-

44 Max Fisher, "The four reasons Russia won't give up Syria, no matter what Obama does", The Washington Post, 5 Eylül 2013, https://www.washingtonpost.com/news/ worldviews/wp/2013/09/05/the-four-reasons-russia-wont-give-up-syria-no-matterwhat-obama-does/, (20 Kasim 2016).

45 Bill Gertz, "Inside The Ring: New Russian beachhead in Syria", The Washington Times, 3 Şubat 2016, http://www.washingtontimes.com/news/2016/feb/3/inside-the-ring-newrussian-beachhead-in-syria/?page=all, (20 Kasım 2016).

46 "Uçakta meşru olmayan unsurlar var", Hürriyet, 11 Ekim 2012, http://www.hurriyet. com.tr/ucakta-mesru-olmayan-unsurlar-var-21670055, (20 Kasım 2016).

47 "Exclusive: Turkey says seizes illegal Iran arms shipment", Reuters, 31 Mart 2011, http://www.reuters.com/article/us-iran-sanctions-un-idUSTRE72U6GJ20110331， (20 Kasim 2016). 
mat çıkmasının ardından İran uçağının BMGK kararı, Rus uçağının ise sivil havacılık kuralları gerekçe gösterilerek Suriye'ye varışı engellenmiştir. Ankara bu tavrı ile İran-Rusya ittifakının askeri açıdan bölgede güçlenmesini kendi politik manevra alanında engellemeye yoluna gitmiştir.

$\mathrm{Bu}$ girişimlere rağmen Suriye krizi konusunda İran-Rusya ittifakının 2015 y1lı itibariyle organize bir yapıya kavuşmasıyla birlikte bölgeye coğrafi yakınlığı bulunan Türkiye'nin tehdit algısında ciddi bir yükselme yaşanmıştır. Konu ile ilgili bir açıklama yapan Cumhurbaşkanı Erdoğan "Esed'in burayı bırakıp gitmesi konusunda hassasiyeti olan var, olmayan var. Esed'i korumaya çalışanlar var. İran ve Rusya bunlardan biri. Şimdi Rusya'nın Suriye'de yaptığı bizim sınırlarımızı ihlal etme olayı. NATO'nun da sert bir ültimatomu oldu. Buna sabretmemiz mümkün değil"48 diyerek söz konusu yardımların saldırganlık boyutuna ulaştı̆̆ını ima etmiştir. Nitekim Rusya'nın oluşturduğu tehdit iki ülke arasında sıcak temasa dönüşmüş ve Kasım 2015'te iki ülke arasında uçak krizi yaşanmıştır.

Karşı ittifakın diğer üyeleri Katar ve Suudi Arabistan açısından Suriye krizinin oluşturduğu tehdit algısının boyutları Türkiye'nin sahip olduğu algıya nispeten farkl1lık göstermektedir. Suriye krizini İran "tehdidi” ile mücadele alanı olarak gören bu devletler İran'ın genel olarak Arap Baharı politikasını kendi rejimleri açısından tehdit olarak algılamaktadırlar. Suudi Arabistan Dışişleri Bakanı Adil Cübeyr vermiş olduğu bir mülakatta İran'ın “yayılmacı" bir politika izlediğinin altını çizerek Tahran yönetiminin devrim sonrası başlattığı saldırgan politikalardan vazgeçmesi gerektiğini belirtmiştir. İran'ın “devrimci ya da ulus devlet olma” arasında bir tercih yapmak zorunda olduğunu söyleyen Cübeyr, bu tutumun Bahreyn, Yemen, Lübnan ve Suriye'de kendilerini rahatsız ettiğini açıklamıştır. ${ }^{49}$ İran'ın “devrim ihracının" hedefinde olan Körfez ülkeleri 2011'de Ortadoğu'yu etkisi altına alan değişim hareketini bu perspektiften değerlendirmiş ve Suriye'yi İran nüfuzunun kırılacağı bir zemin olarak görmüştür. Suriye'de değişim yanlısı bir pozisyon alan Katar ve Suudi Arabistan son dönemlerde özellikle Rusya'nın bölgedeki askeri varlığından rahatsız olarak değişen dengeleri onar-

48 “Erdoğan: Rusya ve İran Esad'1 koruyor”, Sabah, 7 Ekim 2015, http://www.sabah.com. tr/dunya/2015/10/07/erdogan-rusya-ve-iran-esadi-koruyor, (20 Kasim 2016).

49 Samiha Shafy ve Bernhard Zand, "Saudi Foreign Minister: "I Don't Think World War III Is Going To Happen in Syria", Spiegel Online, 19 Şubat 2016, http://www.spiegel. de/international/world/interview-with-saudi-foreign-minister-adel-al-jubeir-on-syrianwar-a-1078337.html, (20 Kasim 2016). 
manın yollarını aramaktadır. Bu bağlamda karşı ittifakın Suriye'ye askeri müdahalesini gündeme getiren açıklamalar yapmışlardır. Katar Dışişleri Bakanı Halid el-Atiyye İran ve Rusya'nın Suriye konusundaki tavrını eleştirerek gerektiği takdirde Türkiye ve Suudi Arabistan ile birlikte bölgeye askeri operasyon düzenleyebileceklerini dile getirmiştir. ${ }^{50}$

\subsection{Tehditle Mücadele Stratejileri Bağlamında Suriye Krizi}

Ortadoğu'daki mevcut çok kutuplu güç dağılımı, Suriye krizinin doğurduğu tehditlerle mücadelede aktörlere "tehdidi dengeleme" veya onun "peşine takılma" seçenekleri sunduğu gibi tehditle mücadelenin sorumluluğunu diğer aktörlere yükleme fırsatını da içinde barındırmaktadır. Gerek ittifaklara dâhil olan Rusya, İran, Türkiye, Katar ve Suudi Arabistan'ın gerekse tehdit algısına rağmen ittifakların dışında kalmayı tercih eden aktörlere örnek olarak Mısır ve BAE'nin Suriye politikası incelendiğinde çok kutuplu bölgesel sistemin stratejik opsiyonlarının uygulamalarına rastlanmaktadır.

İlk olarak rejim yanlısı ittifakın izlediği stratejiye değinmek gerekirse, Rusya ve İran'ın rejime verdiği askeri desteğin, karşı ittifakı dengeleme üzerine inşa edildiği öne sürelebilir. Suriye Ordusu'na eğitim ve muhaliflerle mücadelede danışmanlık desteği sağlayan İran, krizin uluslararasılaştığ 2012 yılından itibaren daha aktif roller üstlenerek karşı ittifakın askeri varlığını dengeleme yolunu tercih etmiştir. Bu bağlamda bölgeye İDM'nin bazı birlikleri, yabancı savaşçılar ve askeri mühimmatlar sevk edilmiştir. ${ }^{51}$ İran'ın askeri yardımlarına paralel olarak Rusya rejimle ikili anlaşmalarını gerekçe göstererek bölgeye çok sayıda askeri sevkiyat gerçekleştirmiştir. Her iki aktör de krizin erken dönemlerinde kendi kapasitesini mobilize ederek kar\$̧1 ittifakı dengeleme girişimlerinde bulunsa da bu çabalar somut bir netice doğurmamıştır. 2015 yılında muhaliflerin özellikle Suriye'nin kuzeyinde ciddi ilerlemeler kaydetmesi, Rusya-İran ittifakının aleyhine bir dengenin oluşmasını sağlamıştır. ${ }^{52}$ Sahadaki bu gelişme İran ve Rusya'yı daha somut

50 “Askeri müdahale gerekiyorsa yaparız", Aljazeera Turk, 21 Ekim 2015, http://www. aljazeera.com.tr/haber/askeri-mudahale-gerekiyorsa-yapariz, (20 Kasım 2016).

51 Max Peck, "Doubling Down on Damascus: Iran's Military Surge to Save the Assad Regime", Foundation for Defense of Democracies, 5 Ocak 2016, http://www. defenddemocracy.org/content/uploads/documents/Doubling_Down_on_Damascus.pdf, (20 Kasim 2016).

52 Şaban Kardaş, “Suriye'ye Rus Müdahalesi: Tıkanmışlığın Restorasyonu”, Ortadoğu Analiz, Cilt. 7 No. 71, (Kasım-Aralık 2015). 
bir ittifakın kurulmasına zorlayarak harici dengeleme stratejisi izlemeye yönlendirmiştir. Bu bağlamda Moskova'da bir araya gelen taraflar gerçekleştirilen görüşmeler neticesinde Suriye Ordusu'nun İran tarafından kara, Rusya tarafindan ise hava operasyonlarıyla desteklenmesi suretiyle dengenin yeniden kurulması konusunda bir anlaşmaya varmıştır. ${ }^{53}$

Suriye krizinin karşı ittifakını oluşturan Türkiye, Katar ve Suudi Arabistan için ise durum biraz farklılık arz etmektedir. Bu ittifak, rejimi devirmeye yönelik uygulamalar göz önüne alındığında krizin başlangıcından günümüze kadar varlığını sürdürmekle birlikte kendi içinde ciddi değişimlere maruz kalmıştır. Özellikle tehdit algılarındaki farklılaşma dikkate alındığında Suudi Arabistan'ı müttefiklerinden ayrıştığı görülmektedir. Suriye krizinin erken dönemlerinde İran'ın etkisinden olduğu kadar Müslüman Kardeşler gibi "İslamcı" grupların varlığından da tehdit algılayan Riyad yönetimi bu açıdan Türkiye ve Katar'dan farklılaşmış ve muhalefet içerisinde bu iki aktörü dengeleme yolunu tercih etmiştir.

Müslüman Kardeşler'in ve radikal grupların benimsediği siyasi projeksiyonu kendi rejimi için tehdit olarak gören Suudi Arabistan, muhalifleri silahlandırırken bu gruplarla ilişki kurmaktan kaçınmıştır. ${ }^{54}$ Suriye Müslüman Kardeşler'inin lideri Muhammed Riyad el-Şafka verdiği bir mülakatta Suudi Arabistan'ın muhaliflere yaklaşımını eleştirmiş ve bu bağlamda Riyad ile Doha arasında bir rekabetin olduğunu kabul etmiştir. ${ }^{55} \mathrm{Bu}$ tehdit algısıyla hareket eden Riyad yönetimi Türkiye ve Katar destekli "İslamcı" grupları dengelemek için milliyetçi ve seküler muhalifleri desteklemiştir. ${ }^{56}$

2014'ün sonlarına kadar devam eden bu rekabet özellikle Suudi Arabistan'dan aldıkları askeri yardımlarla rejime karşı ilerleme kaydeden güneydeki milislerin Hizbullah karşısında varlık gösterememesi ve İran'ın gerek

53 Tim Lister, "Russia's Syria expedition: Why now and what's next?", CNN International, 1 Ekim 2015, http://edition.cnn.com/2015/09/27/world/russia-syria-involvement/, (20 Kasim 2016).

54 Raphaël Lefèvre, "Saudi Arabia and the Syrian Brotherhood", Middle East Institute, 27 Eylül 2013, http://www.mei.edu/content/saudi-arabia-and-syrian-brotherhood, (20 Kasim 2016).

55 Roula Khalaf ve Abigail Fielding-Smith, "How Qatar seized control of the Syrian revolution", Financial Times, 17 May1s 2013, http://www.ft.com/cms/s/2/f2d9bbc8bdbc-11e2-890a-00144feab7de.html, (20 Kasim 2016).

56 Mariam Karouny, "Saudi edges Qatar to control Syrian rebel support", Reuters, 31 May1s 2013, http://www.reuters.com/article/us-syria-crisis-saudi-insight-idUSBRE94U0ZV20130531, (20 Kasim 2016). 
Suriye'de gerekse Yemen'de nüfuzunu arttırması nedeniyle son bulmuştur. ${ }^{57}$ Suudi Arabistan'ın tehdit algısında değişimler meydana getiren bu gelişmeler strateji değişikliğine yansımıştır. İttifak içi dengeleme stratejisinden vazgeçen Suudi Arabistan, daha büyük bir tehdidi (İran-Rusya) dengelemek için Türkiye ve Katar çizgisine kayarak peşine takılma stratejisi izlemeye başlamıştır. Bu stratejinin en somut göstergesi Suudi Arabistan'ın Türkiye ve Katar tarafindan desteklenen Feylak'u Şam, İslam Ordusu ve Ahrar'u Şam ile "İslamcı" grupların çatı oluşumu olarak özetlenebilecek Fetih Ordusu arasındaki negatif yönlü ilişkilerini düzeltmesidir. ${ }^{58}$ Muhalifler arasında ayrım gözetmekten vazgeçen Riyad yönetimi sorun bağlamında daha fazla inisiyatif alarak ve muhalifleri tek çatı altında toplanma girişimlerini üstlenerek strateji değişikliğini açıkça ortaya koymuştur.

Suriye krizi sadece ittifaklara dâhil olan devletlerin değil çok kutuplu bölgesel sistemin sağladığ 1 esneklikten faydalanarak ittifak dışında kalmayı tercih eden ve tehditlerle mücadelenin maliyetlerini diğerlerine yükleyen devletlerin de güvenliğini tehdit eden bir süreçtir. Bu devletlerden bir kaçına değinmek gerekirse, "Arap Baharı" adı verilen halk hareketlerinden etkilenen Misır, "devrimin" ve "karşı devrimin" etkisiyle Suriye krizine yönelik farklı tehdit algıları çerçevesinde bir tutum sergilemiştir. 2012 yılında şiddet olaylarının yoğunlaşması nedeniyle bir tepki olarak Suriye elçisini geri çağıran Mısır 2013'te ise bu ülke ile ikili ilişkilerini kesmiştir. Fakat Temmuz 2013'te "karşı devrim" ile iktidar değişiminin yaşanmasının ardından Mısır, değişen tehdit algısına bağlı olarak Suriye krizini farklı okumaya başlamıştır. Ordu tarafından kurulan kabinenin Dışişleri Bakanı Nebil Fehmi yeni yönetimin Suriye'yle ilişkileri gözden geçireceğini duyurmuş ve "Suriye'de cihada niyetimiz yok" diyerek krize doğrudan taraf olmayacaklarını ilan etmiştir. ${ }^{59}$

Ordunun yönetime el koymasının ardından içeride başta Müslüman Kardeşler olmak üzere "İslamcı" gruplarla yoğun bir mücadeleye giren Kahire

57 Hassan Hassan, "Syria Is Now Saudi Arabia's Problem", Foreign Policy, 6 Haziran 2013, http://foreignpolicy.com/2013/06/06/syria-is-now-saudi-arabias-problem/, $\quad$ (20 Kasim 2016).

58 Raphaël Lefèvre ve Ali el-Yassir, “The Sham Legion: Syria's Moderate Islamists", Carnegie Endowment for International Peace, 15 Nisan 2014, http://carnegieendowment. org/syriaincrisis/?fa=55344, (20 Kasim 2016).

59 “Mısır'ın yeni Suriye politikası açıklandı", Dünya Bülteni, 20 Temmuz 2013, http:// www.dunyabulteni.net/haber $/ 268083 /$ misirin-yeni-suriye-politikasi-aciklandi, (20 Kasim 2016). 
yönetimi, Suriye krizini de bu mücadelenin bölgesel uzantısı olarak okumaya başlamıştır. Bu okuma biçimi Cumhurbaşkanı Abdül Fettah el-Sisi tarafindan açıkça dile getirilmiştir. Sisi bir mülakatta "Korkum şu ki Suriye ordusu düşerse silah ve teçhizatı radikallerin eline geçer ve bu da onlara güç katar. (...) Esad'la muhalefet arasindaki durum ise halledilebilir" ${ }^{\prime 0}$ diyerek Suriye krizine yönelik yaklaşımını ortaya koymuştur. Bu algı üzerinden hareketle Rusya'nın "terör” sorununu bahane ederek Suriye'ye askeri müdahalede bulunmasına destek veren Misır, bu yöndeki girişimlere ise taraf olmayarak pasif bir tutum sergilemeyi tercih etmiş ve tehditlerle mücadelenin sorumluluğunu İran-Rusya ittifakına yüklemiştir.

Suriye krizi bağlamında tehdit algısına sahip olmasına rağmen ittifak dışında kalarak tehditlerle mücadelenin sorumluluğunu diğerlerine yükleyen ülkelere verilebilecek bir başka örnek ise BAE'dir. Kriz uluslararası bir boyut kazanmadan önce Körfez İşbirliği Konseyi (KİK) ve Arap Birliği bünyesinde barışçıl çözüm önerilerine katkıda bulunan BAE, bu dönemde Suriye politikasını körfez ülkeleriyle paralel götürmüştür. Fakat Suriye krizine bölgesel aktörlerin dâhil olması ve muhalefet içerisinde “İslamcı" kimliğinin ön plana çıkması BAE'nin tehdit algısını arttırmıştır. Abu Dabi yönetimi açısından Suriye, bir taraftan başta Müslüman Kardeşler olmak üzere siyasi projeksiyonu bölgedeki otoriter rejimleri tehdit eden örgütlerin etkinliğini genişlettiği diğer taraftan İran gibi bölgesel bir gücün askeri varlığını arttırarak bölgesel bir tehdide dönüştüğü zemin olarak değerlendirilmiştir. ${ }^{61}$ Başka bir deyişle BAE için Suriye iki ayrı tehdidin mücadele alanına evrildiği ve taraf tutmanın maliyetli olduğu bir tabloyu ifade etmiştir. İki yönlü tehdit algısına rağmen krize doğrudan müdahil olmaktan çekinen BAE, çok kutuplu bölgesel sistemin sunduğu avantajlardan faydalanarak tehditlerle mücadelenin sorumluluğunu diğer aktörlere yükleme stratejisi izlemektedir.

\section{Sonuç}

Soğuk Savaş bitiminden Obama dönemine kadar olan süreçte ABD’nin Or-

60 Ahmed Fouad, "Mısır Suriye'de çözümün anahtarı olabilir mi?", Al-Monitor, 25 Ekim 2015, http://www.al-monitor.com/pulse/tr/originals/2015/10/egypt-role-syria-crisis-assad-russia-saudi-arabia.html, (20 Kasım 2016).

61 Ömer el-Hasan, "Körfez Ülkeleri ve Suriye Krizi”, Aljazeera Turk, 15 Ağustos 2012, http://www.aljazeera.com.tr/haber-analiz/korfez-ulkeleri-ve-suriye-krizi, $\quad(20 \mathrm{Kasim}$ 2016). 
tadoğu politikası, bölgesel krizlere yönelik benimsenen müdahaleci stratejik yaklaşım üzerine temellendirilirken Obama dönemiyle birlikte köklü bir değişime uğramıştır. 2001 Afganistan ve 2003 Irak müdahaleleri gibi yüksek maliyetler doğuran müdahaleci anlaysşta değişime giden Obama yönetimi, bu maliyetlerden kurtulmanın yolunun ABD'nin bölgedeki askeri varlığını azaltmaktan ve bölgesel krizlerin maliyetini bölgesel aktörlere yüklemekten geçtiği anlayışını benimsemiştir. Bu değişim neticesinde Ortadoğu, Soğuk Savaş sonrası ABD tarafından domine edilen bir bölge görünümünden bölgesel aktörler arasında güç mücadelelerine sahne olan çok kutuplu bir bölge görünümüne evrilmiştir.

$\mathrm{Bu}$ sistemik değişim aktör davranışlarının yeni güç dağılımı üzerinden şekillenmesine yol açmıştır. Başka bir ifade ile devletler Ortadoğu'daki yeni kriz alanlarına yönelik reaksiyonlarını çok kutuplu güç dağılımını dikkate alarak yeniden dizayn etmişlerdir. Ortadoğu'daki kriz alanları (Suriye, Yemen, Libya) incelendiğinde, devletler tarafından çok sık başvurulan reaksiyonlardan biri olarak ittifakların varlığı dikkat çekmektedir. Özellikle çatışma yoğunluğunun diğerlerine nazaran daha fazla olduğu Suriye örneği ele alındığında, aktörleri ittifaklara yönelten kaygının ve bu kaygıyı gidermeye yönelik izlenilen yöntemlerin çok kutuplu sistemin rekabet ve çatışmaya yol açan yapısal sınırları içerisinde belirlendiği görülmektedir.

\section{Kaynakça}

“Askeri müdahale gerekiyorsa yaparı", Aljazeera Turk, 21 Ekim 2015, (20 Kasim 2016).

"Assad's overthrow "red line" for Iran: supreme leader's aide", Reuters, 20 Ocak 2013.

Bakr, Amena ve Mariam Karouny, "Qatar, allies tighten coordination of arms flows to Syria”, Reuters, 14 May1s 2013.

Bassam, Laila ve Tom Perry, "How Iranian general plotted out Syrian assault in Moscow”, Reuters, 6 Ekim 2015.

“Başkan Obama'nın, Afganistan ve Pakistan'daki Durumun Geleceğine Dair Konuşması”, ABD Diplomatik Temsilcilikler-Türkiye, 1 Aralık 2009.

Bernard, Anne "Syrian Rebels Say Saudi Arabia Is Stepping Up Weapons Deliveries", The New York Times, 12 Eylül 2013. 
Birnbaum, Michael, "The secret pact between Russia and Syria that gives Moscow carte blanche”, The Washington Post, 15 Ocak 2016.

Blomfield, Adrian, "Russian arms ship to make second attempt to deliver helicopters to Syria", The Telegraph, 24 Haziran 2012.

Brooks, Stephen G., G. John Ikenberry ve William C. Wohlforth, "Don't Come Home America: The Case Against Retrenchment", International Security, Cilt: 37, Say1: 3, 2013.

Chivers, C. J. ve Eric Schmitt, "Arms Airlift to Syria Rebels Expands, With Aid From C.I.A", The New York Times, 24 Mart 2013.

Christensen, Thomas J. ve Jack Snyder. Chain Gang and Passed Bucks: Predicting Alliance Patterns in Multipolarity, International Organization, Cilt. 44, No. 2, 1990.

Coghlan, Tom ve Michael Evans, "Russia sends men and arms to prop up dying Assad regime in Syria”, The Weekend Australian, 3 Eylül 2015.

Deutsch, Karl W. ve J. David Singer, "Multipolar Power Systems and International Stability", World Politics, Cilt.16, No.3, 1964.

DeYoung, Karen ve Liz Sly, "Syrian rebels get influx of arms with gulf neighbors' money, U.S. coordination”, The Washington Post, 15 May1s 2012.

Doherty, Regan ve Amena Bakr, "Exclusive: Secret Turkish nerve center leads aid to Syria rebels", Reuters, 27 Temmuz 2012.

El-Hasan, Ömer, "Körfez Ülkeleri ve Suriye Krizi", Aljazeera Turk, 15 Ağustos 2012.

Entous, Adam ve Matthew Rosenberg, "U.S says Iran helps crackdown in Syria", The Wall Street Journal, 14 Nisan 2011.

"Erdoğan: Bayırbucak Türkmenlerinin olduğu yerde DAİŞ yok; Esed rejimini ayakta tutmak için saldırıyorlar", T24, 24 Kasım 2015.

“Erdoğan: Rusya ve İran Esad'1 koruyor”, Sabah, 7 Ekim 2015.

"Exclusive: Turkey says seizes illegal Iran arms shipment", Reuters, 31 Mart 2011.

Fassihi, Farnaz ve Jay Solomon, “Top Iranian Official Acknowledges Syria Role”, The Wall Street Journal, 16 Eylül 2012. 
Fisher, Max, "The four reasons Russia won't give up Syria, no matter what Obama does", The Washington Post, 5 Eylül 2013.

Fouad, Ahmed, “Mısır Suriye'de çözümün anahtarı olabilir mi?”, Al-Monitor, 25 Ekim 2015.

Haynes, Kyle, " Decline and Devolution: The Sources of Strategic Military Retrenchment”, International Studies Quarterly, 2015.

Gertz, Bill, "Inside The Ring: New Russian beachhead in Syria", The Washington Times, 3 Şubat 2016.

Hassan, Hassan, "Syria Is Now Saudi Arabia's Problem”, Foreign Policy, 6 Haziran 2013.

“İran: “Türkiye 'Yeni Osmanlıcılık’ peşinde”, Hürriyet, 12 Ekim 2012.

Kardaş, Şaban, "Suriye’ye Rus Müdahalesi: Tıkanmışlığın Restorasyonu”, Ortadoğu Analiz, Cilt. 7 No. 71, Kasım-Aralık 2015.

Karouny, Mariam, "Saudi edges Qatar to control Syrian rebel support", Reuters, 31 May1s 2013.

Khalaf, Roula ve Abigail Fielding-Smith, "How Qatar seized control of the Syrian revolution”, Financial Times, 17 Mayıs 2013.

Knights, Michael, “Iran's Foreign Legion: The Role of Iraqi Shiite Militias in Syria", The Washington Institute for Near East Policy, 27 Haziran 2013.

Lefèvre, Raphaël ve Ali el-Yassir, "The Sham Legion: Syria's Moderate Islamists", Carnegie Endowment for International Peace, 15 Nisan 2014.

Lefèvre, Raphaël, "Saudi Arabia and the Syrian Brotherhood", Middle East Institute, 27 Eylül 2013.

Lister, Tim, "Russia's Syria expedition: Why now and what's next?", $C N N$ International, 1 Ekim 2015.

Mearsheimer, John J. ve Stephen M. Walt, "The Case for Offshore Balancing”, Foreign Affairs, 13 Haziran 2016.

Mearsheimer, John J., "A Return to Offshore Balancing", Newsweek, 31 Aralık 2008.

Mearsheimer, John J., Back to the Future, International Security, Cilt. 15, No. 1, 1990. 
Mearsheimer, John J., The Tragedy of Great Power Politics, New York: Norton Company Inc, 2001.

"Mısır'ın yeni Suriye politikası açıklandı", Dünya Bülteni, 20 Temmuz 2013.

Monteiro, Nuno P., Theory of Unipolar Politics, New York: Cambridge, 2014.

Morgenthau, Hans J., Politics Among Nations: The Struggle for Power and Peace, New York: McGraw-Hill, 1993.

"Muhalefete karadan havaya füze", Aljazeera Turk, 20 Şubat 2016.

Peck, Max, "Doubling Down on Damascus: Iran's Military Surge to Save the Assad Regime", Foundation for Defense of Democracies, 5 Ocak 2016.

Russett, Bruce M., "An Empirical Typology of International Military Alliances", Midwest Journal of Political Science, Cilt 15, No: 2, 1971.

"Russia dismisses uproar over Syria arms sales", Raw Story, 17 Mayıs 2013.

Schweller, Randall L., Deadly Imbalance: Tripolarity and Hitler's Strategy of World Conquest, New York: Columbia University Press, 1998.

Schweller, Randall L., Unanswered Threats: Political Constraints on the Balance of Power, New Jersey: Princeton University Press, 2006.

Shafy, Samiha ve Bernhard Zand, "Saudi Foreign Minister: "I Don't Think World War III Is Going To Happen in Syria", Spiegel Online, 19 Şubat 2016.

Sinkaya, Bayram, “Arap Baharı Sürecinde İran'ın Suriye Politikası”, Siyaset, Ekonomi ve Toplum Araştırmaları Vakfi, Nisan 2012, No. 53.

Snyder, Glenn H., Alliance Politics, Ithaca: Cornell University Press, 1997. "Uçakta meşru olmayan unsurlar var", Hürriyet, 11 Ekim 2012.

Walt, Stephen M., "Why Alliances Endure or Collapse", Survival: Global Politics and Strategy, Cilt.39, Say1:1, 1997.

Walt, Stephen M., The Origins of Alliances, New York: Cornell University Press, 1990.

Waltz, Kenneth, Uluslararası Politika Teorisi, çev: Osman S. Binatlı, Ankara: Phoenix Yayınevi, 2015. 
Yalçın, Hasan Basri, “ABD, Suriye'de PKK Devleti Kuruyor”, Star, 27 Haziran 2016.

Yalçın, Hasan Basri, Ortadoğu'da Yeni Durum ve Türkiye'nin Dış Politika Stratejisi, Türk Dış Politikası Yıllı̆̆ı 2013. 2015.

Yalçın, Hasan Basri, “Obama Stratejisi ve Ortadoğu” Akademik Ortadoğu, Cilt: 9, Say1: 2, 2015. 